\title{
Mandible Measurements and Dental Midline Deviation after Alveolar Nerve Transection in Growing Rabbits
}

\author{
Medidas Mandibulares y Desviación de la Línea Mediana Dental Luego de la Transección del \\ Nervio Alveolar Inferior en Conejos en Crecimiento
}

"Iván Valdivia Gandur; ${ }^{* *}$ Victoria Tallón Walton; **Patricia Carvalho Lobato;
${ }_{* * * *}$ Vicente Lozano de Luaces \& ${ }^{* *}$ María Cristina Manzanares Céspedes

VAldivia, G. I.; TAllón, W. V.; CARVAlHO, L. P.; LOZANO, L. V. \& MANZANARES, C. M. C. Mandible measurements and dental midline deviation after alveolar nerve transection in growing rabbits. Int. J. Morphol., 29(1):52-56, 2011.

SUMMARY: The relationship between sensitive innervation and normal mandibular bone development has been described in the literature. Therefore, neural damage is a potential cause of osseous deformities, particularly in growing subjects. The aim of this project is to present the mandible measurements obtained after the transection of the inferior alveolar nerve of growing rabbits. A specific surgical protocol was designed to carry out the unilateral nerve transection by avoiding musculoskeletal injuries. Twenty New Zealand White rabbits one week post-weaning were used, 12 as an experimental group and 8 as a control group (Sham operated). The animals were sacrificed 90 days postoperatory, and the mandibles carefully dissected. Dental midline deviation data were obtained under anesthesia, previous to sacrifice. All measurements were obtained with a micron digital caliper. For this study, only anterior-posterior measurements were obtained from five points specifically determined on the rabbit mandible. Each measurement was made three times by the same examiner and the average value was considered. Regarding the anterior-posterior measurements, the molar and incisive regions of the denervated hemimandible were significantly shorter than the corresponding regions in the non-denervated side. The control group did not show these differences. A dental midline deviation was observed, but not always directed on the operated side. However, the deviation values were greater when oriented to the denervated side. These changes did not cause evident deformity or dysfunction in the masticatory system of the animals. They were fed normally and their weight was considered within normal parameters while growing. Despite the biological relationship between sensory inervation and bone morphology, the effect of sensory denervation in early stages of bone growth appears to generate only small alterations on the mandible morphology. However, these alterations do not lead to functional problems in the masticatory system.

KEY WORDS: Mandible; Growth; Development; Anatomy; Dissection; Stomatognathic system.

\section{INTRODUCTION}

Several studies show a relationship between sensitive innervation and normal mandible bone development (Chiego, 1995; Olgart 1992; Storey \& Kenny, 1989; Behrents \& Johnston, 1984; Nakanishi et al., 1994). Therefore, neural damage is a potential cause of osseous deformities, particularly in growing subjects. An experimental design consisting of the transection of the inferior alveolar nerve in growing rabbits has been developed in order to evaluate two parameters of mandible deformity: anterior-posterior mandibulometry and dental midline deviation.

\section{MATERIAL AND METHOD}

A surgical protocol was designed to carry out the unilateral nerve transection in the site where the alveolar inferior nerve enters the bone. The bioethics committee of Barcelona University approved this protocol. Due to the important participation of musculoskeletal elements in bone growth (Moss-Salentijn, 1997; Moss \& Salentijn, 1969; Matsuyuki et al., 2006; Sinsel et al., 2002), the surgery was specifically designed by anatomical dissection to prevent injuries to these structures (Valdivia et al., 2010). Twenty New Zealand rabbits one week post-weaning were used, 12

\footnotetext{
Anatomy Unit, Biomedical Department, Universidad de Antofagasta, Chile.

** Human Anatomy and Embryology Unit, Pathology and Experimental Therapy Department, Bellvitge Health Sciences Campus, Universidad de Barcelona, Spain.

*** Department of Dentistry and Stomatology, Bellvitge Health Sciences Campus, Universidad de Barcelona, Spain.
} 
as an experimental group and 8 as a control group (Sham operated). The animals were sacrificed 90 days postoperatory, and the mandibles extracted. In the dissection process, all tissues attached to skeletal structure were conserved. For this study, only anterior-posterior measurements were obtained from five points specifically established for this objective in the rabbit mandible (Fig. 1 and Table I). A thin layer of soft tissue covering the measurement points was carefully removed using a stereomicroscope and micro-dissection material. In order to allow the ulterior study of the mandibular tissues, periosteum was not detached. A total of five measurements were obtained as described in Figure 1. Each measurement was repeated three times by the same examiner and the average value was considered. In addition, mathematical relations between different segments were calculated.

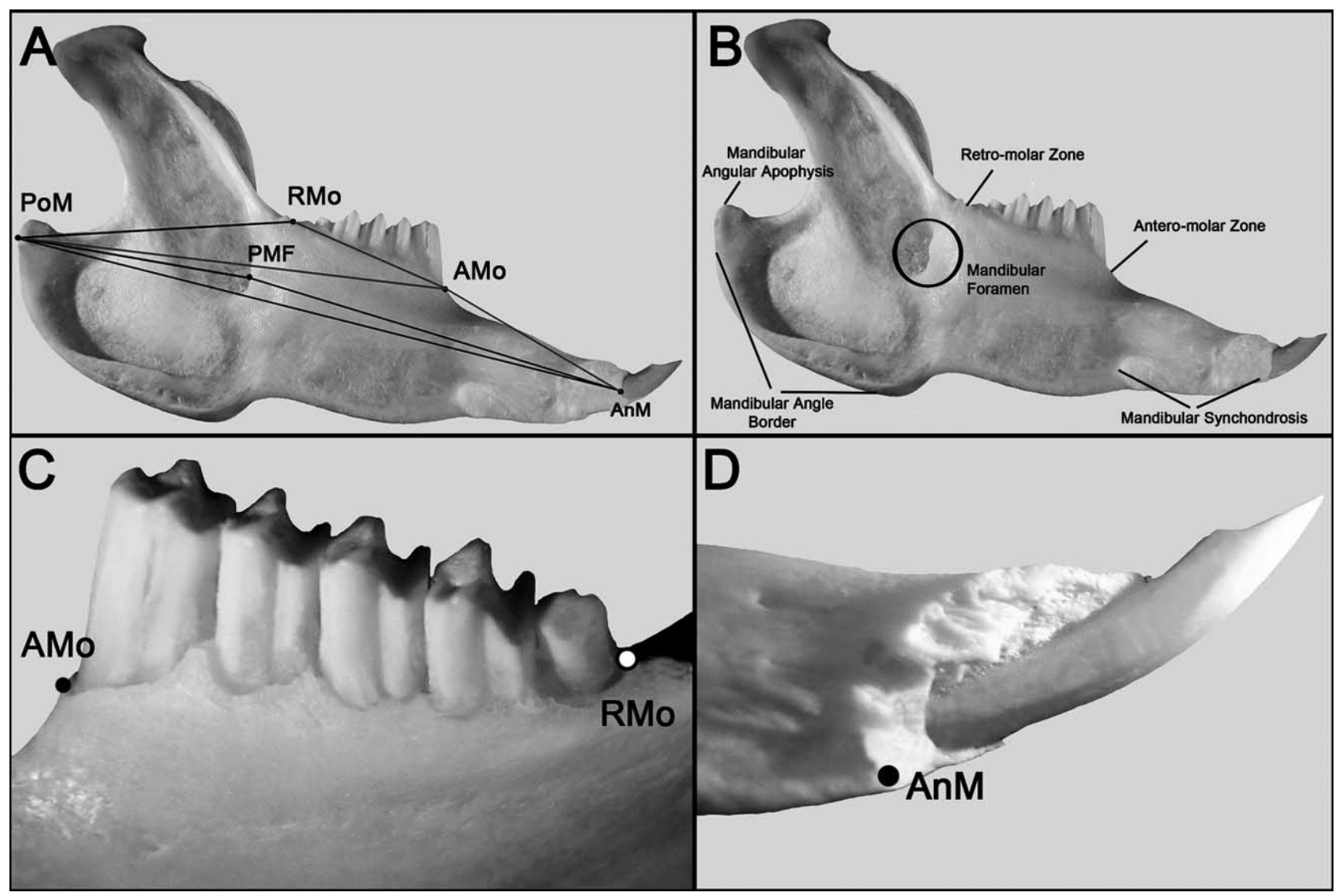

Fig. 1. Mandibular points selected for anteroposterior measurements; A: The Five mandibular points (for the meaning of each acronyms, see Table I). The lines between points indicate several possibilities for measurements in the anteroposterior plane. For this study, only the measures shown in Tables II and III (PoM - AnM, PoM-Rmo, RMo-AMo, AMo-AnM, PMF-AnM) were used; B: Anatomical reference for the points in image A; C and D: Detail for AMo, RMo and AnM points.

Table I. Definition and location of points for mandibular measurements (see Figure 1)

\begin{tabular}{|c|c|c|}
\hline Mandibular point & Definition & Mandibular location \\
\hline AMo & Anterior-molar & $\begin{array}{l}\text { The most anterior and superior point of alveolar bone, located } \\
\text { anterior to the first molar in the anterior-molar area. }\end{array}$ \\
\hline RMo & Retro-molar & $\begin{array}{l}\text { The most posterior and superior point of alveolar bone, located } \\
\text { posterior to the fifth molar in the retro-molar area. }\end{array}$ \\
\hline AnM & Anterior-Mandibular & The most anterior point of mandibular synchondrosis. \\
\hline PoM & Posterior-Mandibular & The most posterior point of mandibular angle border. \\
\hline PMF & $\begin{array}{l}\text { Posterior-Mandibu lar- } \\
\text { Foramen }\end{array}$ & $\begin{array}{l}\text { The most anterior point observed in medial cortical bone } \\
\text { delimiting the mandibular foramen. }\end{array}$ \\
\hline
\end{tabular}


For dental midline deviation measurements, the distance between the midpoints of the narrowest space between central incisors both in the maxilla and the mandible was considered. This measurement was carried out when the animals were anesthetized. Each animal was placed in the supine position and the occipital area of the head in the horizontal plane. In this position, the mandible was manipulated and separated from the maxillary teeth (emulating a mouth opening) and then, without force, was allowed to return to the closed mouth state. When no movement was perceived (around 30 seconds), the measurement was obtained. This process was repeated three times and the measurements obtained were averaged to obtain a final value for each animal. All the measurements were carried out with a micron digital caliper (Mitutoyo ${ }^{\circledR}$ Digimatic Caliper Series 500). Statgraphic Plus 5.1 software was used for statistical analysis.

\section{RESULTS}

Two animals were discarded due to health problems, one from each group. No significant difference was observed in maximum anterior-posterior length between denervated and non-denervated hemimandibles (Table II). However, the anterior-posterior measurements of the molar and incisive region (PMF - AnM in Figure 1) of the denervated hemimandible were significantly lower compared with the values of the non-operated one (Table III). Similarly, significant differences in mathematical relation between the molar-incisive region length and the maximum mandibular length (PMF-AnM/PoM-AnM) was observed, comparing denervated hemimandible and no denervated hemimandible ( $\mathrm{p}$-value: 0,0045 ). The control group did not show these differences. The dental midline deviation was not always directed to the denervated or the sham-operated side. However, the values of the deviation were greater when directed towards the denervated side (Table IV).

Nevertheless, the changes in mandibular measurements did not cause evident deformity or dysfunction in the masticatory system. The animals did not require an adapted diet; fed normally by themselves and their weight was kept within normal parameters while growing.

Table II. Maximum antero-posterior length of mandib le (PoM - AnM). No statistical difference.

\begin{tabular}{|c|c|c|c|}
\hline & Mean of operated side & Mean of NO operated side & $\begin{array}{c}\text { Statistical analysis between } \\
\text { operated side and No } \\
\text { operated side. }\end{array}$ \\
\hline $\begin{array}{l}\text { Experimental rabbit } \\
\qquad(\mathrm{n}=11)\end{array}$ & $\begin{array}{c}\text { Mean PoM - AnM, denervated } \\
\text { hemimandible: } \\
72.70+/-1.16\end{array}$ & $\begin{array}{c}\text { Mean PoM - AnM, } \\
\text { contralateral hemimandible: } \\
72.98+/-1.37\end{array}$ & $P$-value $=0,458$ \\
\hline $\begin{array}{l}\text { Control rabbit } \\
\qquad(\mathrm{n}=7)\end{array}$ & $\begin{array}{c}\text { Mean PoM - AnM, hemimandibles } \\
\text { sham operated: } \\
69,89+/-1,96\end{array}$ & $\begin{array}{c}\text { Mean PoM - AnM, } \\
\text { contralateral hemimandible: } \\
69,59+/-1,88\end{array}$ & $P$-value $=0,115$ \\
\hline
\end{tabular}

Table III. Summary of statistical analysis between different segments of mandibular bone. (E.R.: experimental rabbits; C.R.: control rabbits; DH: Denervated Hemimandible, CH:Contralateral hemimandible; SOH: Sham Operated hemi mandible). *Significant difference.

\begin{tabular}{|c|c|c|c|c|c|c|c|c|}
\hline & \multicolumn{2}{|c|}{ Mean PoM-Rmo } & \multicolumn{2}{|c|}{ Mean RMo-AMo } & \multicolumn{2}{|c|}{ Mean AMo-AnM } & \multicolumn{2}{|c|}{ Mean PMF-AnM } \\
\hline & E. $R(n=11)$ & C.R. $(n=7)$ & E.R $(n=11)$ & C.R. $(n=7)$ & E.R $(n=11)$ & C.R. $(n=7)$ & E.R $(n=11)$ & C.R. $(n=7)$ \\
\hline & $\mathrm{DH} v / \mathrm{s} C H$ & $\begin{array}{l}\mathrm{SOH} v / s \\
\mathrm{CH}\end{array}$ & $\mathrm{DH} v / \mathrm{s} C H$ & $\begin{array}{l}\mathrm{SOH} v / s \\
\mathrm{CH}\end{array}$ & $\mathrm{DH} v / \mathrm{s} C H$ & $\begin{array}{l}\mathrm{SOH} v / s \\
\mathrm{CH}\end{array}$ & $\mathrm{DH} v / \mathrm{s} C H$ & $\begin{array}{l}\mathrm{SOH} v / s \\
\mathrm{CH}\end{array}$ \\
\hline T-student test & $\begin{array}{c}p \text {-value: } \\
0,458\end{array}$ & $\begin{array}{c}p \text {-value: } \\
0,155\end{array}$ & $\begin{array}{c}p \text {-value: } \\
0,216\end{array}$ & $\begin{array}{c}p \text {-value: } \\
0,074\end{array}$ & --- & $\begin{array}{c}p \text {-value: } \\
0,669\end{array}$ & -- & --- \\
\hline $\begin{array}{c}\text { Wilcoxon } \\
\text { Signed ranks } \\
\text { test }\end{array}$ & --- & --- & --- & --- & $\begin{array}{c}\text { p.-value: } \\
0,645\end{array}$ & & $\begin{array}{c}* p \text {-value: } \\
\underline{0,0038}\end{array}$ & $\begin{array}{c}p \text {-value } \\
0,665\end{array}$ \\
\hline
\end{tabular}


Table IV. Deviation dental midline analysis.

\begin{tabular}{|c|c|c|c|c|}
\hline & \multicolumn{2}{|c|}{ IN EXPERIMENTAL RABBITS $(n=11)$} & \multicolumn{2}{|c|}{ IN CONTROL RABBITS $(n=7)$} \\
\hline & $\begin{array}{c}\text { Toward denervated } \\
\text { side }\end{array}$ & $\begin{array}{c}\text { Toward NO } \\
\text { denervated side }\end{array}$ & $\begin{array}{l}\text { Toward sham } \\
\text { operated side }\end{array}$ & $\begin{array}{l}\text { Toward NO sham } \\
\text { operated side }\end{array}$ \\
\hline $\begin{array}{l}\text { Number of } \\
\text { observations }\end{array}$ & 7 & 4 & 4 & 3 \\
\hline $\begin{array}{l}\text { Statistical analysis } \\
\text { using binomial } \\
\text { proportions test }\end{array}$ & \multicolumn{4}{|c|}{ 7/11 v/s 4/7: NO significant difference (p-value 0,766296) } \\
\hline Mean deviation (mm) & $\begin{array}{c}0,817143+/-0,154546 \\
{[0,662597,0,971689]}\end{array}$ & $\begin{array}{c}0,34+/-0,197893 \\
{[0,142107,0,537893]}\end{array}$ & $\begin{array}{c}0,395+/-0,40869 \\
0,0136897,0,80369]\end{array}$ & $\begin{array}{l}0,3333+/-0,188096 \\
{[0,145237,0,521429]}\end{array}$ \\
\hline $\begin{array}{c}\text { Statistical analysis of } \\
\text { means }\end{array}$ & \multicolumn{2}{|c|}{ Significant difference $(p$-value $=0,000805045)$} & \multicolumn{2}{|c|}{ NO significant difference $(\mathrm{p}$-value $=0,859679)$} \\
\hline
\end{tabular}

\section{DISCUSSION}

Some studies show a relationship between the sensory innervation and the function of the masticatory system through so-called nociceptive and proprioceptive reflexes (Okeson, 2003; Lavigne et al., 1987; Willis \& DiCosimo, 1979). This implies an important feedback between the sensitive innervation and the muscular function. According to Moss' theory (Moss \& Salentijn), the action of the functional matrix (masticatory muscles, tongue, etc.) is key for bone formation. Consequently, the alteration of muscle action can alter the mandibular normal growth. Moreover, Petrovic's "servosystem" theory (Lavergne \& Petrovic, 1983; Carlson, 2005) indicates that the mandible always responds to keep the best relationship with the maxilla, with the objective of maintaining a correct occlusal relationship. To accomplish this goal, bone constantly receives signals from the environment. Consequently, both theories imply that the integrity of sensory innervation would be of great importance to maintain the mandible size and shape. Behrents \& Johnston showed that injury to the trigeminal ganglion leading to a lack of facial sensitivity causes small changes in craniofacial morphology. Although this experiment affected both hard and soft tissues, the results of these authors agree with our results in that small changes in bone morphology due to an alteration in the sensory pathway do not cause significant functional changes. Compensation mechanisms that contribute to maintaining the function may be intervening to prevent significant morphological changes.

Several authors suggest that the dental midline should be on the same level of mandibular (or maxillary) and craniofacial midline and one of the goals of orthodontic treatment is to achieve this relation both with a functional and an aesthetic purpose (Thomas et al., 2003; Beyer \& Lindauer, 1998; Johnston et al., 1999). However, natural facial asymmetry and other aspects related to the function, in addition to environmental factors, cause different degrees of deviation of the dental midline (Bishara et al., 1994). Our study revealed that no animal showed coincidence between the maxillary and the mandibular dental midline. A significant difference in the amount of deviation from the mandibular dental midline toward the denervated side was observed, but this fact was not evident to visual inspection nor caused an altered masticatory function.

In conclusion, the macroscopic morphology and function of the mandibular bone in adult rabbits is not affected if neural damage occurs in the principal sensitive nerve while the animals are growing.

VALDIVIA, G. I.; TALLÓN, W. V.; CARVALHO, L. P.; LOZANO, L. V. \& MANZANARES, C. M. C. Medidas mandibulares y desviación de la línea mediana dental luego de la transección del nervio alveolar inferior en conejos en crecimiento. Int. J. Morphol., 29(1):52-56, 2011.

RESUMEN: Se ha descrito una importante relación entre la inervación sensitiva y aspectos biológicos mandibulares. Consecuentemente, el daño a la estructura nerviosa es una causa potencial de alteraciones en el desarrollo mandibular, sobre todo en etapas de crecimiento. El objetivo de este trabajo es presentar mediciones mandibulares realizadas posterior a una lesión del nervio sensitivo en una etapa temprana de crecimiento. Se diseñó un protocolo quirúrgico para realizar la transección del nervio alveolar inferior sin lesionar estructuras musculoesqueléticas. Veinte conejos Neo zelandeses blancos fueron utilizados, una semana postdestete, 12 como grupo experimental y 8 como grupo control. Los animales fueron sacrificados 90 días después y las mandíbulas cuidadosamente disecadas. La información de la desviación de la línea media se obtuvo bajo anestesia, previo al sacrificio. Todas las mediciones se obtuvieron con un calibrador digital. Las medidas antero-posteriores se obtuvieron a partir de cinco puntos específicamente determinados en la mandíbula del conejo. En cuanto a las medidas antero-posteriores, las región molar e incisiva de 
las hemimandíbulas denervadas fueron significativamente menores que la correspondiente del lado no denervado. El grupo control no mostró esta diferencia. La línea media dental siempre se observó desviada, pero no siempre hacia el lado intervenido. Sin embargo, la media de desviación fue mayor cuando ésta se orientó hacia el lado denervado. Estos cambios no causaron deformidad evidente o disfunción en el sistema masticatorio de los animales, los cuales se alimentaron normalmente. El peso de los mismos fue considerado dentro de los parámetros normales. A pesar de la relación biológica entre la inervación sensitiva y la morfología del hueso, el efecto de la denervación sensitiva en las primeras etapas de crecimiento parece generar sólo pequeñas alteraciones en la morfología mandibular. Sin embargo, éstas no conducen a problemas funcionales del sistema masticatorio.

PALABRAS CLAVE: Mandíbula; Crecimiento; Desarrollo; Anatomía; Disección; Sistema estomatognático.

\section{REFERENCES}

Behrents, R. G. \& Johnston, L. E. Jr. The influence of the trigeminal nerve on facial growth and development. Am. J. Orthod., 85:199-206, 1984.

Beyer, J. W. \& Lindauer, S. J. Evaluation of dental midline position. Semin. Orthod., 4:146-52, 1998.

Bishara, S. E.; Burkey, P. S. \& Kharouf, J. G. Dental and facial asymmetries: a review. Angle Orthod., 64:89-98, 1994.

Carlson, D. S. Theories of craniofacial growth in the postgenomic era. Semin Orthod., 11:172-83, 2005.

Chiego, D. J. Jr. The early distribution and possible role of nerves during odontogenesis. Int. J. Dev. Biol., 39:191-4, 1995.

Johnston, C. D.; Burden, D. J. \& Stevenson, M. R.The influence of dental to facial midline discrepancies on dental attractiveness ratings. Eur. J. Orthod., 21:517-22, 1999.

Lavergne, J. \& Petrovic, A. Discontinuities in occlusal relationship and the regulation of facial growth. A cybernetic view. Eur. J. Orthod., 5:269-78, 1983.

Lavigne, G.; Kim, J. S.; Valiquette, C. \& Lund, J. P. Evidence that periodontal pressoreceptors provide positive feedback to jaw closing muscles during mastication. $J$. Neurophysiol., 58:342-58, 1987.

Matsuyuki, T.; Kitahara, T. \& Nakashima, A. Developmental changes in craniofacial morphology in subjects with Duchenne musculardystrophy. Eur. J. Orthod., 28:42-50, 2006.
Moss, M. L. \& Salentijn, L. The primary role of functional matrices in facial growth. Am. J. Orthod., 55:566-77, 1969.

Moss-Salentijn, L. Melvin L. Moss and the functional matrix. J. Dent. Res., 76:1814-7, 1997.

Nakanishi, T.; Takahashi, K.; Aoki, C.; Nishikawa, K.; Hattori, T. \& Taniguchi, S.Expression of nerve growth factor family neurotrophins in a mouse osteoblastic cell line. Biochem. Biophys. Res. Commun., 198:891-7, 1994.

Okeson, J. Neuroanatomía funcional y fisiológica del sistema masticatorio. $5^{\text {a }}$ ed. Barcelona, Elsevier, 2003.

Olgart, L. M. Involvement of sensory nerves in hemodynamic reactions. Proc. Finn. Dent. Soc., 88:403-10, 1992.

Sinsel, N. K.; Opdebeeck, H. \& Guelinckx, P. J. Mandibular condylar growth alterations after unilateral partial facial paralysis: an experimental study in the rabbit. Plast. Reconstr. Surg., 109:181-9, 2002.

Storey, A. T. \& Kenny, D. J. Growth, development, and aging of orofacial tissues: neural aspects. Adv. Dent. Res., 3:1429, 1989.

Thomas, J. L.; Hayes, C. \& Zawaideh, S. The effect of axial midline angulation on dental esthetics. Angle Orthod., 73:359-64, 2003.

Valdivia I.; Lozano de Luaces, V. \& Manzanares, M.C. Inervación sensitiva y crecimiento mandibular: Propuesta de modelo experimental para acceso quirúrgico al nervio alveolar inferior preservando estructuras musculoesqueléticas en Conejo New Zealand White posdestetados. Int. J. Morphol., 2010.

Willis, R. D. \& DiCosimo, C. J. The absence of proprioceptive nerve endings in the human periodontal ligament: the role of periodontal mechanoreceptors in the reflex control of mastication. Oral Surg. Oral Med. Oral Pathol., 48:108$15,1979$.

Correspondence to:

Iván Valdivia Gandur

Unidad de Anatomía

Departamento Biomédico

Universidad de Antofagasta

CHILE

Email: ivaldivia@uantof.cl

Received: 03-08-2010

Accepted: $24-10-2010$ 